\title{
ULTRAMICROSCOPIC CHANGES IN THE PARATHYROID GLANDS AND THYMUS AFTER IMMUNOSTIMULATION IN RATS
}

\author{
Olga AVILOVA ${ }^{1}$, Victoria EROKHINA ${ }^{2}$ \\ ${ }^{1}$ Department of Human Anatomy, Kharkiv National Medical University, Ukraine \\ 2 Department of Histology, Cytology and Embryology, Kharkiv National Medical University, Ukraine \\ Received 26 Febr 2019, Accepted 11 Apr 2019 \\ https://doi.org/10.31688/ABMU.2019.54.2.02
}

\section{Abstract}

Background. The burden of immunodeficiency and infectious diseases is rapidly increasing worldwide. Thus, it becomes necessary to find effective and affordable immunomodulatory drugs that may modify the response of the immune system.

Objectives. To investigate ultramicroscopic changes that occur in parathyroid glands and thymus of male rats after administration of the immunomodulatory agent imunofan.

Methods. Thirty-six WAG matured male rats were divided randomly into two groups. The first group received imunofan in a dosage of $0.7 \mathrm{mg} / \mathrm{kg}$ animal body weight by intramuscular injection. Rodents were sacrificed on the $3^{\text {rd }}$ and $30^{\text {th }}$ day after injection and specimens were dissected out and processed for electron microscopy. The second group served as control and was provided $0.9 \%$ soluble sodium chloride.

Results. The results showed that imunofan exposure caused marked ultramicroscopic changes in parathyroid glands and thymus of rats. On the $3^{\text {rd }}$ day after injection, the amount of the active chief cells significantly increases. A significantly increased number of secretory granules is recognized as the ultrastructural hallmark of chief cells change. Thymus in this term of imunofan administration showed no

\section{Résumé}

L'ultramicroscopie des glandes parathyroïdes et du thymus des rats suite à l'immuno-stimulation

Contexte. Le fardeau de l'immunodéficience et des maladies infectieuses augmente rapidement dans le monde entier. Il devient donc nécessaire de trouver des médicaments immunomodulateurs efficaces susceptibles de modifier la réponse du système immunitaire. Objectifs. Etudier les modifications ultramicroscopiques qui se produisent dans les glandes parathyroïdes et le thymus de rats après l'administration de l'agent immunomodulateur imunofan.

Méthodes. Trente-six rats mâles matures WAG ont été divisés en deux groupes. Le premier groupe a reçu l'imunofan à une dose de $0,7 \mathrm{mg} / \mathrm{kg}$ de poids corporel de l'animal par injection intramusculaire. Le second groupe a servi de contrôle et a été fourni avec $0,9 \%$ de chlorure de sodium soluble. Les rongeurs ont été sacrifiés les 3-ème et 30-ème jours après l'injection et les échantillons ont été traités pour la microscopie électronique.

Résultats. Les résultats ont montré que l'exposition à l'imunofan entraînait des modifications ultramicroscopiques marquées des glandes parathyroïdes et du thymus chez le rat. Le troisième jour après l'injection, 
significant ultrastructural changes in comparison to control group. On the $30^{\text {th }}$ day after the administration, the examination revealed that all the glands of the experimental rats have big amounts of active cells with well-developed secretory apparatus. Floccular or particulate material was observed in the enlarged intercellular spaces surrounded by three or more chief cells. A significant amount of the secretory granules as the material might be excreted by exocytosis into the intercellular spaces. Electron microscopy of thymus revealed that imunofan injection causes changes in organ as a result of the activation of cell-mediated and antibody-mediated immunity on $30^{\text {th }}$ day. Apparently, it also causes temporary delay of age-related thymic involution.

Conclusion. The dynamics of changes in the electronic microscopic structure of rats' parathyroid glands and thymus indicates a high degree of organs reactivity in response to immunotropic drug administration.

Keywords: immunostimulation, parathyroid glands, thymus, ultrastructure, imunofan.

\section{INTRODUCTION}

Humans live in a world that is heavily populated by both pathogenic and non-pathogenic antigens, and that contains a vast array of toxic or allergenic substances that threaten normal homeostasis ${ }^{1}$. One of the systems that use a complex variety of protective mechanisms to control and usually eliminate organisms and toxins, as well as respond to challenging circumstances, is the immune system. Every day the human organism is confronted with hundreds of weakening and disorganizing risk factors that may significantly deplete the immune system ${ }^{2,3}$. This leads to the fact that the burden of immunodeficiency and infectious diseases is rapidly increasing worldwide. Thus, it becomes necessary to find effective and affordable immunomodulatory drugs that may modify the response of the immune system ${ }^{4,5}$.

Immunoregulation, the major process of self-defense, appears to be more complex than has been previously thought, involving the central nervous and endocrine systems. Clinical observations suggest that hematological, oncological, and immunological disorders known for their immune pathogenesis are associated with alterations of the endocrine homeostasis. Thus, the endocrine system is one of the body's instruments to regulate and modulate its immune response. Many of the ideas presented by these pioneering scientists preceded the knowledge that was necessary to understand the mechanisms by which la quantité de cellules principales actives contenant de nombreux granules de sécrétion augmente. Le thymus n'a montré aucun changement ultrastructural significatif par rapport au groupe témoin. Le 30-ème jour, les glandes parathyroïdes des rats expérimentaux ont une grande quantité de cellules actives avec un appareil sécrétoire bien développé. Le matériel floculaire est observé dans les espaces intercellulaires élargis. Le produit des granules de sécrétion est excrété par exocytose dans les espaces intercellulaires. La microscopie électronique du thymus a révélé que l'injection d'imunofan provoque l'activation de l'immunité à médiation cellulaire et à médiation anti-anticorps le 30-ème jour. Apparemment, cela provoque également un retard temporaire de l'involution thymique liée à l'âge.

Conclusions. La dynamique des modifications de la structure au microscope électronique des glandes parathyroïdes et du thymus de rat indique une réactivité élevée en réponse à l'administration de médicaments immunotropes.

Mots-clés: immunostimulation, parathyroïdes, thymus, ultrastructure, imunofan.

hormones affect lymphoid cells and vice versa ${ }^{6}$. While the relationship between immune and endocrine reactions seems obvious, the close links between morphological features of the immune response are the object of increasing scrutiny by scholars ${ }^{2,7}$.

In the available literature, a full coverage of data on the morphological reactivity of parathyroid glands and thymus after immune stimulation in the experiment does not exist, so the study of this issue is vital for the modern medicine and pharmacology. Certain hopes rely on derivatives of thymic hormones, however, the effects of this group on the endocrine organs have not yet been properly considered ${ }^{8}$.

In view of the above, electron microscopic study of the immune and endocrine system organs' structural features is essential for the development of new approaches for effective correction of the immune and endocrine systems.

The AIM OF THE STUDY was to evaluate the peculiarities of ultramicroscopic structure of the rats' parathyroid glands and thymus after experimental immunostimulation.

\section{Materials AND Methods}

\section{Animals}

The experiment was carried out on 36 WAG matured male rats, with initial body weight of 180-200 g. The structure of the immune and endocrine systems 
of the rodent organs is not fundamentally different from those of humans, thus, they were used in the following experimental work. The maintenance and manipulation of animals was carried out in compliance with the requirements of bioethics and the "General Ethical Principles of Animal Experiments" adopted by the First National Congress on Bioethics (Kyiv, 2001), the requirements of the "European Convention for the Protection of Vertebrate Animals Used for Experimental and Other Scientific Purposes" (Strasbourg, 1986), the principles of the Helsinki Declaration on the Human Approach to Animals ${ }^{9}$. The experimental research was carried out on the basis of the laboratory center of morphological research of Kharkiv National Medical University (Kharkiv, Ukraine). Experimental protocols were approved by the institution's ethical committee.

\section{Experimental design}

Rats were randomly divided into two groups. The control and experimental series consisted of animals of the same age. Immune stimulation with the help of imunofan was selected as an experimental model. Imunofan is a medication used for treatment of immunological disorders including immunodeficiency. Imunofan contains hexapeptide Arg- $\alpha$-Asp-Lys-Val-Tyr-Arg, as an active pharmacological substance. The first group of animals received imunofan in a dosage of $0.7 \mathrm{mg} / \mathrm{kg}$ of body weight, by intramuscular injection in the $3^{\text {rd }}$ and $30^{\text {th }}$ day of experiment. The second group served as a control and was provided $0.9 \%$ soluble sodium chloride. An ultramicroscopic examination of the parathyroid glands and thymus has been performed. Animals used in the study were culled by cervical dislocation of the neck and parathyroid gland and thymus samples were removed from the experimental rats and tissue in the $3^{\text {th }}$ and $30^{\text {th }}$ day after the injections. The parathyroid glands were extracted according to the original method, which has been described in detail in the patent ${ }^{10}$. The thymus was dissected with the help of the original instrument which has been described in detail in patent ${ }^{11}$.

\section{Electron microscopy}

Tissue samples were fixed in a glutaraldehyde fixator according to Karnovsky for 24 hours. After this, the material was kept in $1 \%$ osmium tetraoxide according to Palade for 1 hour, dehydrated in ethanol of increasing concentration and absolute acetone, poured with a mixture of epoxy resins (epon-araldit). Polymerization was carried out for 36 hours at $60^{\circ} \mathrm{C}$. Ultrathin sections were cut using an ultramicrotome UMTP-4 of Sumy Electron factory (Ukraine), contrasted in the uranyl acetate solution. Also, sections were treated with a Lead citrate solution that enhances the contrasting effect. Received samples were investigated in an electron microscope EM-125 with the following photographing. Photographs of adjacent sections were taken with a digital camera at $\times 8000$ magnification.

\section{Results}

Histologically, the parathyroid glands are bounded by a thin connective tissue capsule that overlies a network of adipose tissue, blood vessels and glandular parenchyma. The amount of stromal fibroadipose tissue increases with aging, eventually comprising approximately $50 \%$ of the gland volume in elderly. Connective tissue septa separate gland into small irregular lobules, that contain mainly densely packed dense cords of cells clustered around capillaries.

The parenchymal cells of the parathyroid gland of control animals are classified under a microscope into two main types of cells: chief cells and oxyphil cells. Principal (chief) cells are the more numerous of the parenchymal cells of the parathyroid. Chief cells play a central role in calcium homeostasis, by releasing the appropriate amount of parathyroid hormone to correct or maintain normal blood calcium levels. When blood calcium levels decrease, the parathyroid glands secrete parathormone (PTH), activating osteoblasts to secrete osteoclast-stimulating factor and to suppress bone formation. As a result, dormant osteoclasts are activated, and the formation of new osteoclasts is induced, initiating bone resorption and ultimately leading to calcium ions being released from the bone and transferred to the bloodstream

Chief cells are small, polygonal cells, with a centrally located nucleus of rounded shape. The cytoplasm of the chief cells has typical organelles that are involved in protein synthesis. Depending on the stages of secretory cycle, all chief cells could be classified into inactive and active types. The cytoplasm of inactive light cells contains poorly developed synthetic organelles and infrequent secretory granules. There are numerous lipid droplets, lysosomes or glycogen inclusions. Lysosomes differ from secretory granules in larger sizes and high electron density.

Dark chief cells, that represent the active stage of the secretory cycle, are oval or polygonal in shape. The plasma membranes of adjacent chief cells have a tortuous course, which is justified by the presence of complex interdigitations (Fig. 1). The nuclei are oval or spherical, with occasional shallow invaginations. The cells have rich free ribosomes and a rough endoplasmic reticulum. The Golgi complexes contain numerous prosecretory granules. The secretory granules of different sizes are located around the Golgi complexes and peripheral cytoplasm. Some of them are situated close to the plasma membrane. 


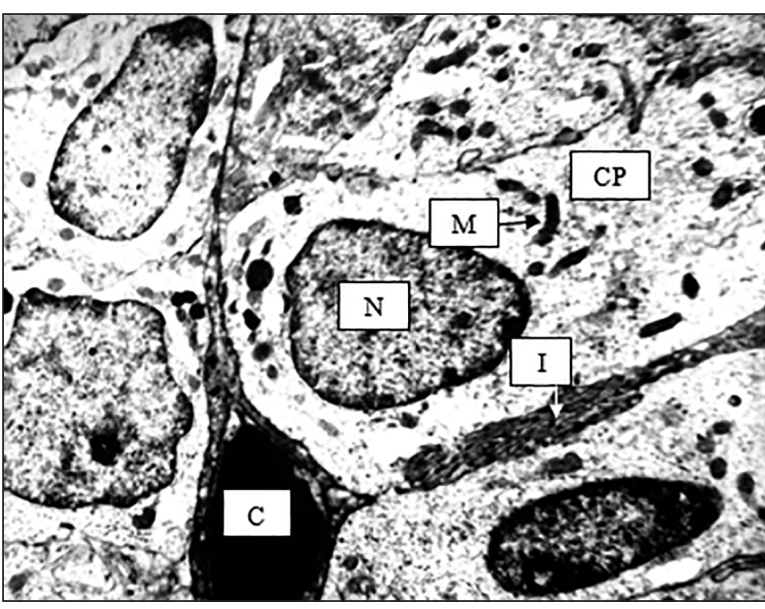

Figure 1. Parathyroid gland of the intact rat. TEM. Magnification $\times 8000$.

$\mathrm{CP}$ - chief parathyrocyte, $\mathrm{N}$ - nucleus, I - interdigitation, $\mathrm{M}$ - mitochondria, $\mathrm{C}$ - blood capillary.

Oxyphil cells constitute a minor portion of the parenchymal cells. Their cells are larger, stain darker, and are much fewer than chief cells. Oxyphil cells appear in small rare clusters, and their function is unknown, although some investigators suggest that they are inactive chief cells $\mathrm{s}^{12}$. The key morphological difference of this type is the abundant cytoplasm filled with numerous large mitochondria. The rough endoplasmic reticulum is scarce and the Golgi complex associated with few prosecretory granules is poorly developed. A few secretory granules, lysosomes, lipid droplets and glycogen particles are present.

Electron microscopic examination and morphometric analysis showed that the structure of the parathyroid glands of the experimental animals appeared to be moderately different from parathyroid glands of control rats. On the $3^{\text {rd }}$ day after injection of the immunomodulatory drug, the amount of the active chief cells significantly increases. Most of the dark chief para-thyrocytes have an irregular elongated shape, clear boundaries and well-defined intercellular contacts (Fig.2). Cells are joined by multiple interdigitations for increasing surface area participating in the regulation of metabolism, as a result of increased secretory activity. The uneven surface is typical for cell nuclei, due to occasional invaginations of nuclear membranes. The nuclear electron density is higher in comparison with control animals. Golgi apparatus and rough endoplasmic reticulum are prominent in all chief para-thyrocytes. At the same time, numerous free ribosomes and polysomes are distributed in the cytoplasm of chief cells. A greatly increased number of secretory granules is recognized as the ultrastructural hallmark of chief cells change. Coated vesicles are observed in the Golgi region and occasional

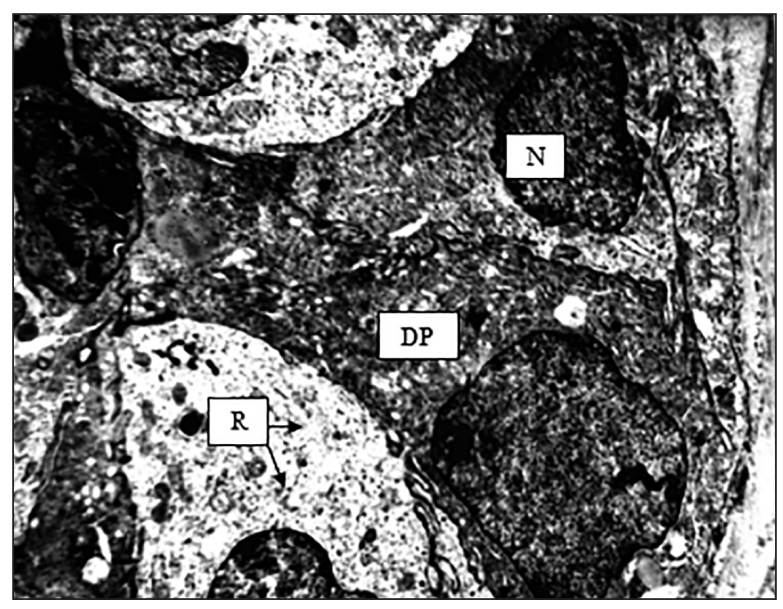

Figure 2. Parathyroid gland of the experimental rat (3rd day). TEM. Magnification $\times 8000$.

DP- dark chief parathyrocyte, $\mathrm{N}$ - nucleus, $\mathrm{R}$ - free ribosomes.

secretory granules are also distributed close to the plasmalemma. Granule contents communicated directly with the intercellular space through an opening in the fused portion of the limiting membrane. Electron-dense vesicles similar to the secretory granules are found in the intercellular space. Perhaps it might be result of the exocytosis.

On the other hand, the structure of oxyphil para-thyrocytes will not undergo any significant changes. The principal morphological difference of the oxyphil cells is great amount of the mitochondria and many large lysosomes.

On the $30^{\text {th }}$ day after the administration of imunofan, electron microscopic examination shows that all the glands of the experimental rats have big amounts of active cells. The plasmalemma of adjacent chief cells is relatively smooth, with occasional indentations, and the nuclei with occasional invaginations are oval or spherical in shape. The chief cells had rich free ribosomes and abundant mitochondria. The Golgi complexes are relatively well-developed and contain prosecretory granules near the trans-face. However, secretory granules in the cytoplasm are rare. Flocular or particulate material is observed in the enlarged intercellular spaces surrounded by three or more chief cells. The experiment in rodents has revealed that the level of secretory activity is not always related to the amount of the secretory granules, as the material might be excreted by exocytosis into the intercellular spaces (Fig. 3).

Electron microscopic study demonstrates that the rat parathyroid glands contain a rich capillary network. Endothelium is thin and contains numerous fenestrae. Small foamy cystic vacuoles are found in the cytoplasm of the endothelial cells. Activation 


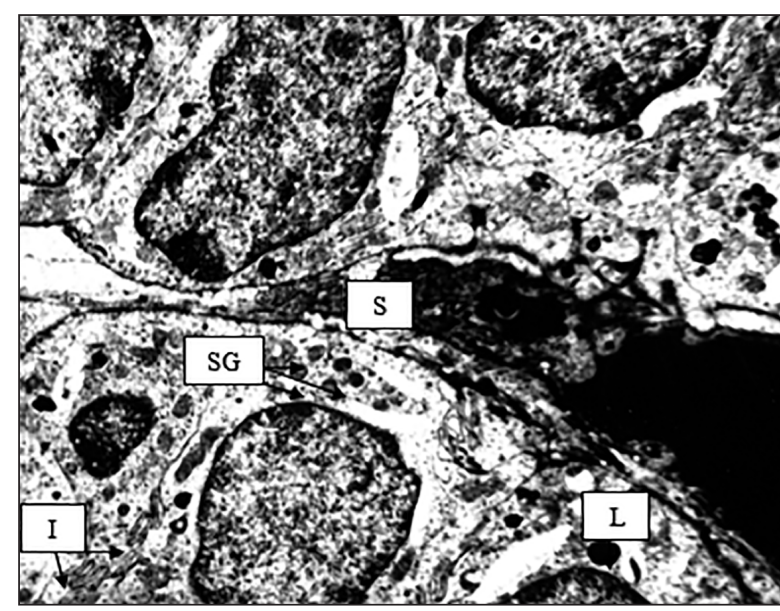

Figure 3. Parathyroid gland of the experimental rat (30th day). TEM. Magnification $\times 8000$.

$\mathrm{SG}$ - secretory granules, I - interdigitation, L- lysosome, $\mathrm{S}-$ perivascular space.

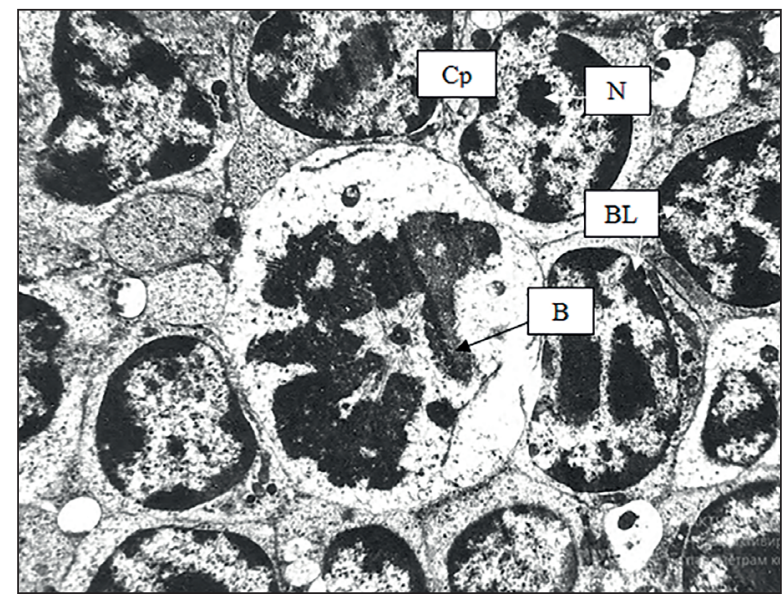

Figure 5. Thymic cortex of the experimental rat (30th day). TEM. Magnification $\times 8000$. BL - big lymphocyte, $\mathrm{N}$ - nucleus, $\mathrm{Cp}$ - cytoplasm, B - blast form cells at the different stages of division.

of pinocytosis processes has been identified in the endotheliocytes, which is apparently associated with intensification of parathyroid hormone excretion processes. The structure of oxyphilic para-thyrocytes does not undergo significant changes, however, their number has decreased.

The cellular composition of the cortex of the intact matured rats' thymus is represented by two main populations - lymphocytes and reticuloepithelial cells. Lymphocytes of the control group animals' thymus have a regular rounded or slightly elongated shape, with a smooth outer surface, and are characterized by a high nuclear-cytoplasmic ratio. The thymic cortex appears darker compared to the medulla area, due to the high density of cortical thymocytes, medium and small lymphocytes, having large hyperchromic nuclei and a narrow rim of the cytoplasm.

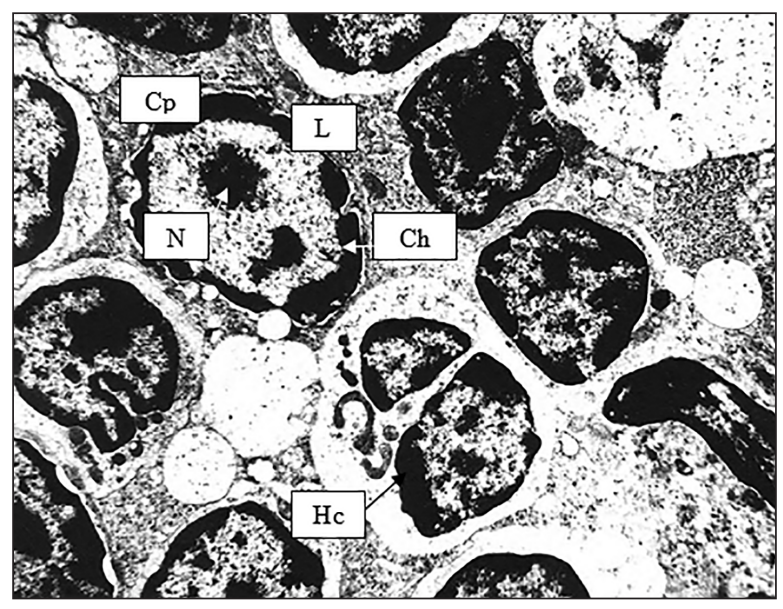

Figure 4. Thymic cortex of the intact rat. TEM. Magnification $\times 8000$.

L- lymphocyte, $\mathrm{N}$ - nucleus of the lymphocyte, $\mathrm{Ch}$ - chromatin, $\mathrm{Cp}$ - cytoplasm, Hc- Hassal's corpuscle.

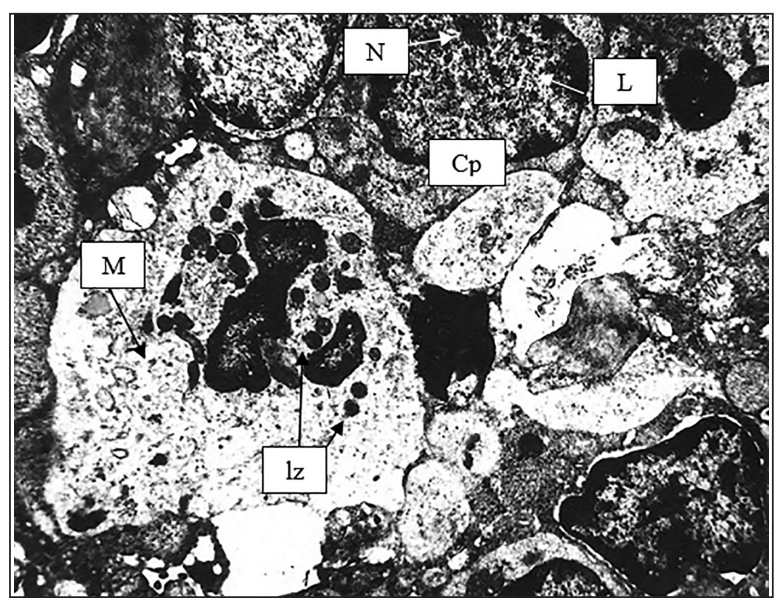

Figure 6. Thymic cortex of the experimental rat (30th day). TEM. Magnification $\times 8000$. L - lymphocyte, $\mathrm{M}$ - active macrophage with large number of autophagosomes, $\mathrm{lz}$ - lyzosomes, $\mathrm{N}$ - nucleus, $\mathrm{Cp}$ - cytoplasm.

Subcapsular zone is represented by several rows of large lymphoblasts. In this zone, mitoses are detected.

Well-developed agranular endoplasmic reticulum is represented mainly by tubules and cisterns. The elements of the smooth endoplasmic reticulum are connected with the cisterns of the granular endoplasmic reticulum and the cell membrane. The mitochondrial matrix of lymphocytes is characterized by a significant electron-optical density. The lysosomal apparatus is represented by primary lysosomes, secondary lysosomes, and residual bodies.

The medulla is lightly stained, contains less numbers of small-diameter lymphocytes, compared with the cortical layer. Here are also isolated plasma cells. The epithelioreticular cells of the medulla are large, nuclei are light, rounded. Mitoses in the cells of the medullary layer are rare. 
The characteristic feature of the medulla was the presence of Hassall's corpuscles, which were concentric clusters of star-forming peripheral thyrocytes (Fig. 4). In addition, in the medullar layer, there are large epithelial cells with rounded, weak or average electron density, nucleus, and the presence in the cytoplasm of granules or vacuoles filled with an amorphous substance.

An ultramicroscopic study of the thymus of adult rats on the $3^{\text {rd }}$ day after the administration of imunofan showed no significant changes in the ultrastructure of the thymus. It may evidence yet the early time to emphasize and notice the impact of the imunofan.

On the $30^{\text {th }}$ day after the injection, significant changes in the structure of all thymic elements are observed. The appearance of a significant number of large lymphocytes, blast forms of cells at different stages of division, is noted (Fig.5). Active macrophages are revealed with plasmalemma invaginations, long cytoplasmic processes with which they contact one another, as well as lymphocytes. Macrophage cytoplasm contains a large number of autophagosomes and phagocytosed cell fragments (Fig.6).

The presence of active macrophages indicates a high level of lymphocytopoiesis on the background of the immunostimulating effect of imunofan. A characteristic feature is the fact that significant changes in the cellular composition of the thymus are observed in the late periods on the $30^{\text {th }}$ day of the experiment, whereas on the $3^{\text {rd }}$ day the ultrastructure of the thymus of the experimental groups does not differ from that of the control groups. This is confirmed by literature data on the mechanisms of the drug ${ }^{13}$.

\section{Discussion}

In a response to imunofan in a dosage of 0.7 $\mathrm{mg} / \mathrm{kg}$, there were observed intensive changes of the ultrastructure of parathyroid glands and thymus, that explain the active reaction to exogenic influence.

The introduction of imunofan in rats caused marked changes in the ultrastructure of the parathyroid gland on the $3^{\text {rd }}$ day after injections, namely, promotes increasing amounts of organelles that are involved in protein synthesis. However, on $3^{\text {rd }}$ day of drug administrationn there were no noted any significant changes in the thymic structure, that is explained in yet early way the changes occur.

The most positive changes in the parathyroid and thymic structure after immunostimulator intake appeared on the later terms of observation $\left(30^{\text {th }}\right.$ day) which may be related to the pharmacological action of the immunomodulatory drug. Apparently, this dynamics indicates the partial temporary delay of age-related thymic involution. The study revealed that the most significant changes have been observed in chief para-thyrocytes, whereas ultrastructure of oxiphil cells remains practically the same as in control group.

The obtained data reveal the thymus active role in mature rats' adaptation to external factors, that is of great interest in the further investigation of the immunomodulating properties of imunofan usage in juvenile rats. Moreover, the dynamics of ultramicroscopic changes of parathyroid glands and the thymus has a similar direction, which seem to suggest about the inextricable link of the immune and endocrine systems in the regulation of homeostasis.

Consequently, the administration of imunofan positively influences the morpho-functional state of the parathyroid glands and thymus. Imunofan is a synthetic derivative of the thymopoetin thymic hormone and has the ability to activate proliferation and differentiation of T-lymphocytes, by activating the products of a variety of factors controlling the growth and development of cells. The above data suggest that imunofan may be used to correct the immune parameters, both on the lymphoid tissue of the thymus and secretory parenchyma of the parathyroid glands.

\section{Conclusions}

The principal change in the parathyroid glands of experimental rats compared to control animals of a similar age is the transformation of the population of inactive chief cells into active cells, in a more active stage of their secretory cycle. Experiments such as low injection of estrogen, isoproterenol, and calcitonin, pinectomy, stimulate chief cells to enter the active stage ${ }^{14}$. Moreover, cells were characterized by an electron-transparent cytoplasm which contained numerous organelles that are involved in protein synthesis and secretory granules. A similar condition was reported by Dar in a histo-morphological study of the parathyroid gland in female Kuttanad ducks ${ }^{15}$.

Khaitov et al described, that administration of imunofan stimulates the synthesis of interleukin-2, which leads to increased synthetic processes in the nucleus and cytoplasm ${ }^{16}$. Similar signs of increased functional activity of the parathyroid glands in electron microscopic studies have been described by Chen et al in Wistar rats ${ }^{17}$.

Kashchenko et al suggested that administration of imunofan on the background of immunosuppression leads to the development of reactive changes in the thyroid gland, aimed at normalizing its structure during the month ${ }^{18}$.

The most significant findings of our study are related to chief cells, as they are active synthetic 
cells. Some scientists believe that oxyphil cells are derivatives of the chief cells as aging or some metabolic derangement, since transitional forms between these cell types can be found ${ }^{19}$. Oxyphil cells increase in number in parathyroid glands of patients with chronic kidney disease and are even more abundant in patients receiving treatment for hyperparathyroidism with calcitriol and the calcimimetic cinacalcet ${ }^{20}$.

Chen et al noticed that oxyphil cells may produce parathyroid hormone in response to prolonged stimulation of the parathyroid glands, and also produce autocrino-paracrine factors, such as parathyroid-associated protein and calcitriol. It is likely that the activation of calcium receptors of the chief para-thyrocytes plays a crucial role in the genesis of these cells $s^{14}$. The existence of water-clear cells is confirmed in some animals, which may represent the hyperfunction of the parathyroid gland. The presence of water-clear cell is associated with parathyroid hyperplasia or parathyroid adenoma. Water-clear cells were not detected in the present study.

Similar to our research data, Bobrysheva investigated the cell profile in the subcapsular and inner zones of thymic cortex after the impact of imuno$\mathrm{fan}^{13}$. The number of damaged cells was significantly lower on $15^{\text {th }}$ and $30^{\text {th }}$ days, which indicates the drug contribution to the restoration of thymic structure. In our research, on the $30^{\text {th }}$ day in comparison to the $3^{\text {rd }}$ day of administration, vast positive changes on the ultramicroscopic level of thymus were observed, suggesting the importance of studying the balance between thymic lymphocytes and their microenvironment treated with immunomodulatory drugs.

Studying the effect of another immunomodulator drug - polyoxidonium - on immunohistochemical level, Struchko GYu revealed that its use causes the increase of all cells in all the thymic compartments, especially in cortex in the account of dentritic cells and macrophages ${ }^{5}$. This was confirmed in our study on ultramicroscopic level, where it was noted a great number of active macrophages.

However, for the recognition of imunofan as a universal drug with a broad spectrum of action, there are not enough data on its effect on the immune organs at the cellular and tissue levels. Thus, a comprehensive study of the interaction of the morpho-functional state of not only thymus but of parathyroid glands against the background of the use of the immunomodulator Imunofan is an important and promising task of modern immunomorphology, which has both fundamental and applied significance.

\section{Compliance with Ethics Requirements:}

„The authors declare no conflict of interest regarding this article"

„The authors declare that all the procedures and experiments of this study respect the ethical standards in the Helsinki Declaration of 1975, as revised in 2008(5), as well as the national law."

„All institutional and national guidelines for the care and use of laboratory animals were followed"

"No funding for this study"

Acknowledgments. The research was conducted on the basis of Kharkiv National Medical University, Ukraine. Hence, we are gratefully thankful for the technical support and the spiritual guidance of the research unit.

Authors' contributions. Authors were the main researchers and performed the experimental work, as well as analyzed the data and prepared the manuscript.

\section{REFEREnCES}

1. Descotes J. Immunotoxicology of drugs and chemicals: an experimental and clinical approach. 3rd ed. Vol. 1, Principles and methods of immunotoxicology. Amsterdam; Boston: Elsevier; 2004;3(1): 398.

2. Avilova O, Sheyan D, Marakushin D, Erokhina V, Gargin V. Ultrustructural changes in the organs of the immune system under the influence of xenobiotics. Georgian Medical News. 2018;(6):132-7.

3. Elmore SA. Enhanced histopathology of the immune system: a review and update. Toxicol Pathol. 2011; 40:148 - 156.

4. Saroj P, Verma M, Jha K. An overview on immunomodulation. Journal of Advanced Scientific Research. 2012; 3(1): 7-12.

5. Struchko GYu, Merkulova LM, Moskvichev EV. Morphological changes in the thymus after applying o polyoxidonium. Fundamentalniye issledovaniya. 2012;5(1):197-202.

6. Manley K, Han W, Zelin G, Lawrence DA. Crosstalk between the immune, endocrine, and nervous systems in immunotoxicology. Current Opinion in Toxicology 2018;10:37-45.

7. Cesta MF, Malarkey DE, Herber TR, Brix A, Sills RC, editors. Nonneoplastic lesion atlas: a guide for standardizing terminology in toxicologic pathology for rodents [Internet]. Research Triangle Park: National Toxicology Program; [2014]. Available from: https://ntp.niehs.nih.gov/index.cfm

8. Patt YZ, Hersh EM, Adebite M. New approaches to the evaluation of immunomodulation by thymic hormones. Annals of the New York Academy of Sciences 2006; 332(1):160-171.

9. Andersen ML, Winter LMF. Animal models in biological and biomedical research - experimental and ethical concerns. An Acad Bras Cienc 201;91:e20170238.

10. Kaschenko SA, Tatarenko DP, Erokhina VV, Honcharova MV, Ivanov OS, Bobrysheva AO, inventors; Tatarenko DP, assignee. Modified method for thyroid preparation in rats. UA patent 81378. 2013 Jun 25.

11. Avilova OA, Sheyan DM, Tereshchenko AO, Lyitenko MA, Ladna IV, inventors; Kharkiv National Medical University, assignee. Double scissors for one-stage autopsy of laboratory animals and cutting out organs' parts at different angles. Ukraine patent UA 130916 U. 2018 Dec. 26. 
12. Kanter M. The occurrence of the oxyphil cells in parathyroid glands: an ultrastructural study in cattle and horses. Eastern Journal of Medicine. 1996;1:51-54.

13. Bobrysheva IV. Morphological and functional features of the thymus of rats of different periods in health and at experimental immunostimulation. Morphologia. 2013;7(4):11-7.

14. Chen H, Senda T, Emaru S, Kubo K. An update on the structure of the parathyroid gland. The Open Anatomy Journal. 2013; 5:1-9.

15. Dar FA, Maya S, Chungath JJ, Ashok N, Patki HS Histomorphological study of the parathyroid gland in female Kuttanad ducks (Anas platyrhynchos domesticus). Veterinary World. 2013;6(11):941-944.
16. Khaitov RM, Alekseev LP. Immunogenetics and biomedicine. Russian Physiological Journal named after I. M. Sechenov 2010; 96(8):787-805.

17. Chen H, Hayakawa D, Emura S. Effect of low calcium diet on the structure of the rat parathyroid gland. Okajimas Folia Anatomica Japonica. 2001;78(5):153-160.

18. Kashchenko SA, Goncharova MV. Submicroscopic changes in the thyroid gland of rats after the immunosuppression. Morphologia. 2013;7(3):49-53.

19. Cinti S, Sbarbati A. Ultrastructure of human parathyroid cells in health and disease. Microscopy Research and Technique. 1995;32:164-179.

20. Ritter CS, Haughey BH, Miller B, Brown AJ. Differential gene expression by oxyphil and chief cells of human parathyroid glands. J Clin Endocrinol Metab. 2012;97(8):1499-1505. 